\title{
ANALISIS ADOPSI TEKNOLOGI PEMBUATAN PETIS DARI LIMBAH PENGOLAHAN PINDANG DI KABUPATEN SUKABUMI
}

\author{
ANALYSIS OF TECHNOLOGY ADOPTION TO PRODUCE PETIS FROM PINDANG \\ PROCESSING WASTE IN SUKABUMI REGENCY
}

\author{
Sukma Budi Prasetyati ${ }^{*}$, Aef Permadi ${ }^{2}$, Andin H. Taryoto ${ }^{3}$ \\ ${ }^{1}$ Politeknik Kelautan dan Perikanan Karawang, Jalan Lingkar Tanjungpura, Karangpawitan, Kecamatan \\ Karawang Barat, Kabupaten Karawang, Jawa Barat 41315 \\ ${ }^{2}$ Politeknik Ahli Usaha Perikanan (AUP), Jl. Raya Pasar Minggu, RT.1/RW.9, Jati Padang, Kec. Ps. \\ Minggu, Kota Jakarta Selatan, Daerah Khusus Ibukota Jakarta 12520 \\ ${ }^{3}$ Politeknik Ahli Usaha Perikanan (AUP), Kampus Bogor, Jl. Cikaret No.1,2, RT.01/RW.03, Cikaret, Kec. \\ Bogor Sel., Kota Bogor, Jawa Barat 16132
}

Teregistrasi I tanggal: 07 April 2020; Diterima setelah perbaikan tanggal: 20 Mei 2021; Disetujui terbit tanggal: 31 Mei 2021

\begin{abstract}
ABSTRAK
Adopsi dalam proses penyuluhan adalah penerimaan responden terhadap inovasi teknologi yang diberikan melalui kegiatan penyuluhan. Tujuan dari penelitian ini adalah untuk menganalisis hubungan antara variabel karakteristik inovasi $\left(\mathrm{X}_{1}\right)$; karakteristik pengolah pindang $\left(\mathrm{X}_{2}\right)$; serta metode pelatihan dan kunjungan $\left(\mathrm{X}_{3}\right)$ terhadap tingkat adopsi inovasi teknologi pembuatan petis (Y) pada pengolah pindang. Jumlah responden yang diamati adalah 41 orang. Analisis deskriptif digunakan sebagai metode analisis. Selain itu juga digunakan analisis korelasional rank-spearman dan uji z untuk menentukan signifikansi hubungan antar variabel. Hasil analisis menunjukkan bahwa nilai koefisien korelasi variabel $\mathrm{X}_{1}$ dan $\mathrm{Y}$ adalah 0,640 yang berarti kuat, signifikan dan searah; nilai koefisien korelasi variabel $\mathrm{X}_{2}$ dan $\mathrm{Y}$ adalah 0,358 yang berarti rendah, signifikan dan searah; dan nilai koefisien korelasi variabel $\mathrm{X}_{3}$ dan $\mathrm{Y}$ adalah 0,578 yang berarti cukup kuat, signifikan dan searah. Berdasarkan analisis usaha diketahui bahwa produk petis memberikan tambahan pendapatan bagi pengolah pindang.
\end{abstract}

Kata kunci: Inovasi, Karakteristik Pengolah, Pelatihan, Petis

\begin{abstract}
Adoption in the extension learning process is a changing of knowledge, attitude, or skill after received innovation technology from extension agent. The aims of this research were knowing the correlation between innovation characteristic $\left(X_{1}\right)$; potential users characteristic $\left(X_{2}\right)$; training and visit method $\left(X_{3}\right)$ to the innovation adoption rate of pindang processors $(Y)$. Observed respondents were 41. The data analysis method that was used were descriptive analysis; correlation rank spearman analysis, and z-test to determine correlation significance between the variables. The results showed that the correlation coefficient value between $X_{1}$ and $Y$ was 0,640 which mean high, significant, and positive; the correlation coefficient value between $X_{2}$ and $Y$ was 0,358 which mean low, significant, positive; and the correlation coefficient value between $X_{3}$ and $Y$ was 0,578 which mean moderate high, significant, positive. According to business analysis, petis has been giving additional revenue for pindang processors.
\end{abstract}

Keywords: innovation, producer characteristics, training, petis

Korespondensi penulis:

*Email: sukmabudiprasetyati@gmail.com

DOI: http://dx.doi.org/10.15578/plgc.v2i2.8874

Copyright (C) 2021, PELAGICUS: Jurnal IPTEK Terapan Perikanan dan Kelautan 


\section{PENDAHULUAN}

Masyarakat perikanan menghadapi beberapa persoalan diantaranya berkaitan dengan aspek teknologi produksi, modal, iklim dan pasar. Persoalan-persoalan tersebut erat hubungannya dengan kegiatan penyuluhan (Amanah, 2006). Kehadiran penyuluh diharapkan membuka akses masyarakat pada program-program pembangunan yang menjadi prioritas pemerintah. Penyuluh berperan sebagai pemberi informasi atau inovasi, mediator, dan menjalankan fungsi edukasi dan berperan sangat tinggi di tengah masyarakat (Wijianto, 2008). Untuk mengenalkan inovasi teknologi pengolahan, dibutuhkan kegiatan penyuluhan yang tepat sehingga mempermudah penerimaan sasaran terhadap inovasi teknologi tersebut. Tingkat adopsi inovasi pelaku utama menunjukkan adanya pengaruh penyuluhan terhadap perubahan pengetahuan, ketrampilan dan sikap sasaran. Perubahan perilaku yang terjadi pada pelaku utama adalah output yang dapat diukur dan dapat dievaluasi capaiannya. Kabupaten Sukabumi sendiri mempunyai potensi pengolahan perikanan yakni produk pindang yang disebut cue. Data sekunder yang diperoleh dari keterangan Seksi Produksi Dinas Kelautan dan Perikanan Kabupaten Sukabumi menyebutkan bahwa produksi pindang tongkol di Kabupaten Sukabumi mencapai 7.788 ton pada tahun 2014 dan 9.691 ton pada 2015.

Sumardjo (2006) dalam Anwas (2013) menyatakan bahwa persoalan penyuluhan pada masa otonomi daerah antara lain adalah adanya kesalahan persepsi pada pihak-pihak penanggungjawab penyuluhan di daerah; kesan Penyuluh dianggap kurang profesional; persepsi tertentu di kalangan masyarakat tentang dampak penyuluhan; kemudian adanya anggapan bahwa penyuluhan di masa lalu pernah diwarnai kepentingan politik dari organisasi tertentu; dan Penguasa Daerah yang tidak fokus pada penyuluhan karena ketidakjelasan output serta tidak tampaknya outcome secara langsung. Erlina \& Kurniasari (2007) dalam penelitiannya di Kabupaten Sukabumi menyatakan bahwa sebanyak 59,09\% respondennya merasa bahwa kunjungan penyuluh hanya 1-2 kali saja dalam sebulan, bahkan sebanyak 9,09\% menyatakan belum pernah mendapatkan kunjungan dari penyuluh. Pernyataan tersebut lebih ditegaskan lagi oleh Pertiwi et al. (2011) yang menyebutkan bahwa $10,8 \%$ respondennya menyatakan pernah mengikuti kegiatan penyuluhan paling tidak tiga kali dalam setahun, sementara sebagian besar lainnya bahkan tidak pernah mengikuti kegiatan pelatihan dan penyuluhan. Masyarakat perikanan menghadapi beberapa persoalan diantaranya berkaitan dengan aspek teknologi produksi, modal, iklim dan pasar. Persoalan-persoalan tersebut erat hubungannya dengan kegiatan penyuluhan. Penyuluhan adalah upaya mengubah perilaku individu atau kelompok agar tahu, mau dan mampu memecahkan masalah yang dihadapi supaya dapat hidup lebih baik dan bermartabat (Amanah, 2006).

Inovasi teknologi yang dipilih adalah teknologi pembuatan petis ikan dari limbah cair hasil pemindangan. Limbah cair hasil pemindangan dapat digunakan juga sebagai bahan baku pembuatan kerupuk ikan, namun produk petis dipilih karena memiliki beberapa keunggulan diantaranya adalah proses pengolahan yang relatif mudah; bahan tambahan lebih sedikit sehingga modal produksi lebih rendah; waktu pengolahan singkat; dan investasi peralatan pengolahan lebih sedikit. Harinta (2010) menjelaskan bahwa tingkat adopsi inovasi pada masyarakat dipengaruhi oleh faktor-faktor yaitu: karakteristik inovasi; karakteristik masyarakat calon pengguna; proses pengambilan keputusan adopsi; media yang digunakan; dan kemampuan 
penyuluh. Faktor karakteristik inovasi dan karakteristik calon pengguna dipilih menjadi variabel yang diukur setelah sebelumnya dilakukan pengamatan terhadap kondisi lapangan dimana penelitian dilaksanakan. Faktor lain yaitu pengambilan keputusan adopsi tidak menjadi variabel yang diamati sebab inovasi teknologi pengolahan petis masih dalam tahap introduksi (pengenalan), sedangkan faktor saluran yang digunakan dan kualifikasi penyuluh juga tidak menjadi variabel yang diukur karena di lokasi penelitian tidak terdapat penyuluh perikanan yang membina wilayah tersebut. Introduksi inovasi teknologi pengolahan hasil perikanan membutuhkan metode penyuluhan yang tepat sehingga mempermudah dan mempercepat proses adopsi inovasi. Beberapa metode penyuluhan dapat digunakan untuk melaksanakan proses introduksi inovasi, salah satunya adalah melalui kegiatan pelatihan dan kunjungan. Metode pelatihan dan kunjungan digunakan untuk meningkatkan kemandirian, manejemen usaha, kemmapuan teknis dari bebrbagai usaha perikanan. Pelatihan adalah suatu kegiatan alih pengetahuan dan ketrampilan baik berupa teori maupun praktek melalui metode partisipatif, dimana porsi praktek melalui simulasi lebih banyak dibandingkan ceramah teori (Permen KP No. 30/2014).

Berdasarkan uraian di atas, maka tujuan penelitian adalah menganalisis hubungan karakteristik inovasi terhadap tingkat adopsi inovasi teknologi pengolah pindang di Kabupaten Sukabumi; menganalisis hubungan karakteristik inovasi teknologi, serta hubungan intensitas pelatihan dan kunjungan terhadap tingkat adopsi inovasi pada pengolah pindang di Kabupaten Sukabumi.

\section{BAHAN DAN METODE}

Waktu dan Tempat

Penelitian dilakukan di Kecamatan Bantargadung Kabupaten Sukabumi yang terletak pada koordinat 6.9271806 LS dan 106.7031303,10.7 BT pada bulan Januari - Maret 2017. Kecamatan tersebut dipilih karena memiliki sentra pengolahan pindang dan karena di lokasi tersebut terdapat Pusat Pelatihan Mandiri Kelautan dan Perikanan (P2MKP) Pengolahan Pindang Tradisional.

\section{Variabel dan Indikator Penelitian}

Penelitian difokuskan pada tiga variabel $\mathrm{X}$ setelah dilakukan studi literatur, misalnya pada penelitian Harinta (2010), Sutarto (2008), Permen KP No. 30/2014; serta pengamatan pendahuluan terhadap masyarakat di lokasi penelitian.

Variabel karakteristik inovasi teknologi $\left(\mathrm{X}_{1}\right)$ diukur menggunakan indikator keuntungan relatif; kesesuaian inovasi dengan kondisi sasaran; kemudahan penerapan inovasi; triabilitas (ketercobaan); dan observabilitas (keteramatan). Karakteristik calon pengguna yaitu karakteristik calon pengguna $\left(\mathrm{X}_{2}\right)$ diukur menggunakan indikator umur; tingkat pendidikan; pendapatan; dan pengalaman dalam berusaha. Metode pelatihan dan kunjungan $\left(\mathrm{X}_{3}\right)$ diukur menggunakan indikator persepsi sasaran terhadap pelatihan dan kunjungan yang dilakukan oleh petugas. Variabel Y yaitu tingkat adopsi inovasi diukur dengan persentase bahan baku yang diolah dan waktu yang dibutuhkan responden untuk menerapkannya. Instrumen yang digunakan dalam pengambilan data primer meliputi lembar uji pre dan post test, kuisioner, dan panduan wawancara. Bagan kerangka pikir penelitian dapat dilihat pada Gambar 1. 


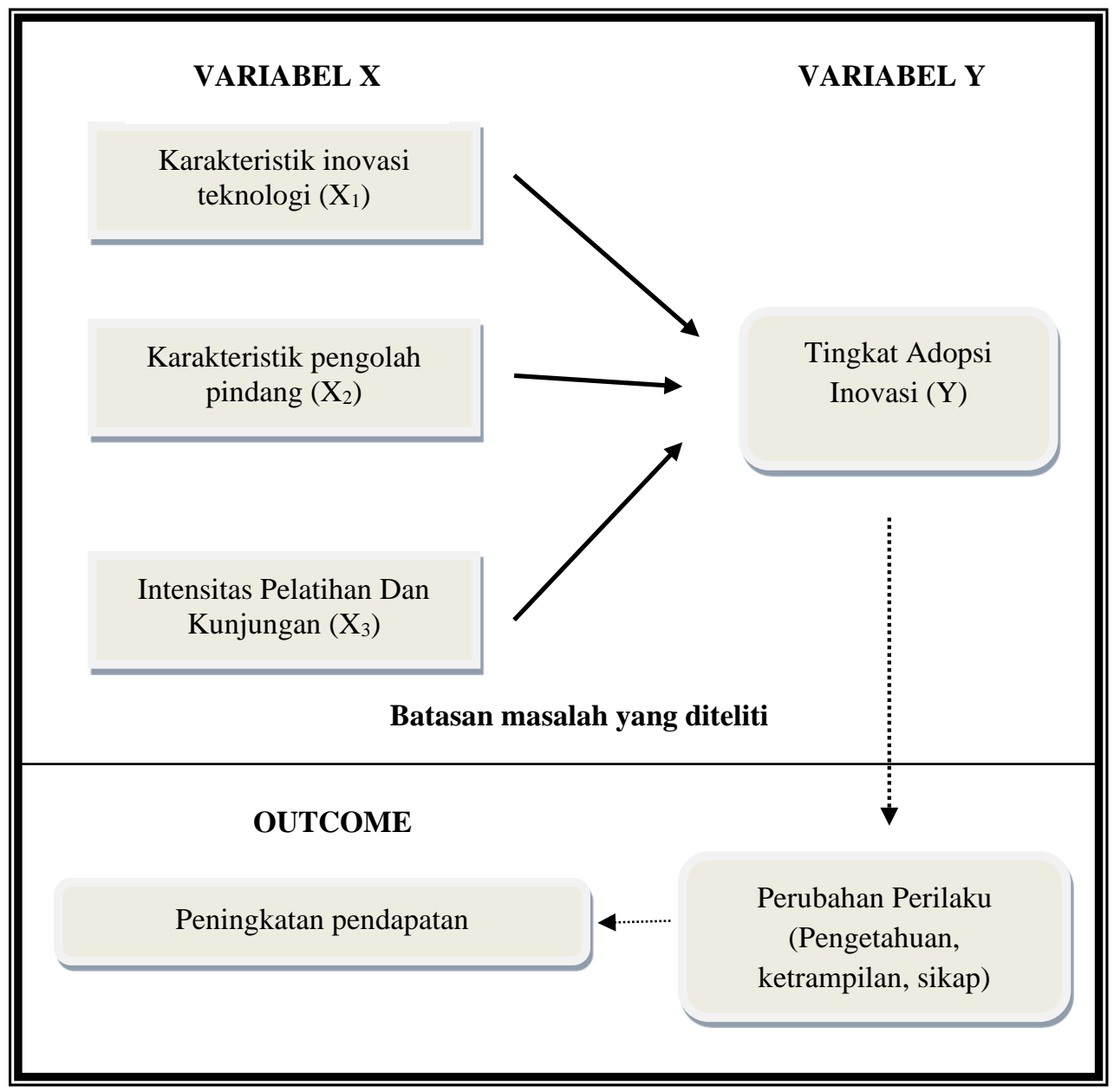

Gambar 1. Kerangka Pikir

Figure 1. Thinking Framework

\section{Populasi dan Sampel}

Populasi yang diamati adalah pengolah pindang yang berada di Kecamatan Bantargadung Kabupaten Sukabumi serta pernah mengikuti pelatihan Sanitasi dan Higiene oleh Pusat Pelatihan Mandiri Kelautandan Perikanan (P2MKP) Minanggala. Jumlah populasi yang ada berdasarkan data dari P2MKP Minanggala adalah 70 orang.

Berdasarkan jumlah populasi yang telah diketahui, jumlah sampel ditentukan menggunakan rumus Slovin (Maimun et al., 2014) dengan ukuran ketidaktelitian $5 \%$ adalah 59 orang. Akan tetapi pada saat hendak dilakukan pengamatan, sebanyak 29 orang dalam kondisi tidak berproduksi. Jumlah populasi awal menyusut menjadi 41 orang sehingga keseluruhannya diambil sebagai sampel.

\section{Analisis Data}

Metode analisis data yang digunakan adalah statistika deskriptif yaitu statistika yang mendeskripsikan atau memberikan gambaran terhadap obyek yang diteliti melalui data sampel atau populasi tanpa melakukan analisis lanjutan dan membuat kesimpulan secara umum (Sugiyono dalam Widianto 2015). Data yang disajikan dalam analisis deskriptif biasanya berupa tabel, grafik atau diagram. Dalam statistika deskriptif biasanya menampilkan informasiinformasi berupa mean (nilai rata-rata); median (nilai tengah); serta mode (frekuensi terbesar).

Selanjutnya digunakan analisis $t$ Test Paired Two Sample yang berguna untuk menguji perbedaan rata-rata dari dua variabel dengan menggunakan 
sampel yang sama dimana data diambil dari sampel sebelum dan sesudah perlakuan tertentu. Analisis ini dipakai untuk menguji apakah terdapat peningkatan rata-rata pada pengetahuan responden sebelum dan sesudah mendapatkan pelatihan (Maimun et al., 2013). Penghitungan $t$-Test Paired Two Sample menggunakan bantuan Microsoft Excel. Hipotesis yang disusun dalam analisis ini adalah sebagai berikut:

Ho : $\mu_{1}>\mu_{2}$; tidak terdapat peningkatan rata-rata pengetahuan pada pengolah pindang.

$\mathrm{Ha}: \mu_{1} \leq \mu_{2}$; terdapat peningkatan ratarata pengetahuan pada pengolah pindang.

Dengan kriteria pengambilan keputusan $\mathrm{t}_{\text {stat }}>\mathrm{t}_{\text {critical one tail maka Ho ditolak. }}$

Selain itu digunakan juga analisis korelasi untuk mengamati kekuatan hubungan antara dua variabel atau lebih dalam skala-skala tertentu. Analisis korelasi yang dipilih adalah korelasi Spearman sebab data tidak terdistribusi normal dan berupa data dalam skala ordinal (Neolaka, 2014). Rumus korelasi Spearman jika terdapat nilai dengan ranking yang sama adalah sebagai berikut:

$$
\begin{gathered}
r_{s}=\frac{\sum x^{2}+\sum y^{2}-\sum d^{2}}{2 \sqrt{\sum x^{2} \sum y^{2}}} \\
\sum x^{2}=\frac{N^{3}-N}{12}-\sum T_{x} \\
\sum y^{2}=\frac{N^{3}-N}{12}-\sum T_{y} \\
\sum T=\frac{t^{3}-t}{12}
\end{gathered}
$$

\footnotetext{
Dimana: $r_{\mathrm{s}}:$ Koefisien korelasi Spearman

$\mathrm{x} \quad$ : Nilai variabel $\mathrm{x}$

$\mathrm{y}:$ Nilai variabel y

$\mathrm{t}$ : Banyak observasi pada ranking yang sama
}

Interpretasi koefisien nilai $r$ dapat dilihat pada Tabel 1 berikut.

Tabel 1. Interpretasi nilai $\mathrm{r}$ Table 1. Interpretation of $r$ value

\begin{tabular}{cc}
\hline \hline Interval Koefisien & Korelasi \\
\hline $\pm 0,80- \pm 1,000$ & Sangat kuat \\
$\pm 0,60- \pm 0,799$ & Kuat \\
$\pm 0,40- \pm 0,599$ & Cukup kuat \\
$\pm 0,20- \pm 0,399$ & Rendah \\
$\pm 0,00- \pm 0,199$ & Sangat rendah \\
\hline \hline
\end{tabular}

Sumber: Maimun et al. (2013)

Analisis usaha atau investasi kemudian dilakukan untuk mengetahui kelayakan atau perkembangan usaha. Analisis usaha penting untuk memberikan gambaran bagi produsen dalam menentukan apakah usaha tersebut menguntungkan atau tidak. Metode analisis yang digunakan antara lain: Revenue Cost Ratio (R/C Ratio); Payback Period (PP) dan Break Even Point (BEP) (Wahyuningsih et al., 2013).

\section{HASIL DAN BAHASAN}

HASIL

Analisis Hasil Pre dan Post Test Analisis deskriptif

Perubahan perilaku diukur melalui aspek kognitif (pengetahuan); aspek afektif (penerimaan/tanggapan); serta aspek psikomotorik (peniruan). Pada aspek kognitif, instrumen yang digunakan berupa lembar soal pre dan post test yang diberikan pada saat kegiatan pelatihan untuk mengukur apakah ada perubahan pengetahuan sebelum dengan sesudah diberikannya informasi selama kegiatan pelatihan. 
Tabel 2. Analisis Deskriptif Nilai Pre dan Post Test

Table 2. Descriptive analysis of Pre and Post Test Value

\begin{tabular}{lccc}
\hline \hline & & $\begin{array}{c}\text { Nilai Pre } \\
\text { Test }\end{array}$ & $\begin{array}{c}\text { Nilai Post } \\
\text { Test }\end{array}$ \\
\hline Mean & $:$ & 42,50 & 85,01 \\
Median & $:$ & 42,85 & 85,71 \\
Mode & $:$ & 57,14 & 100 \\
Kurtosis & $:$ & -0.58511 & -0.23479 \\
Skewness & $:$ & -0.5906 & -0.80523 \\
Count & $:$ & 41 & 41 \\
\hline
\end{tabular}

Data Tabel 2 menunjukkan bahwa rata-rata hitung dari hasil pre test adalah 42,50 dan post test adalah 85,01. Nilai tersebut menunjukkan adanya peningkatan pengetahuan secara faktual sebagai hasil dari pelatihan. Hasil ini menunjukkan indikasi bahwa sebagian besar peserta pelatihan mendapatkan nilai di atas nilai rata-ratanya baik sebelum maupun sesudah pelatihan yang artinya sebagian besar peserta telah memiliki informasi mengenai materi yang diberikan pada saat pelatihan dan informasi tersebut semakin bertambah setelah pelatihan. Nilai median sebelum pelatihan adalah 42,85 sedangkan nilai median sesudah pelatihan adalah 85,71. Kedua nilai median tersebut nilainya lebih tinggi dibandingkan nilai meannya.

\section{t-Test: Paired Two Sample For Means}

Tabel 3 memperlihatkan bahwa nilai Pearson correlation yang menyatakan kualitas hubungan kedua data yang diukur adalah 0,7483 . Nilai ini menunjukkan bahwa pengetahuan responden sebelum dan sesudah dilaksanakannya pelatihan memiliki hubungan yang kuat. Nilai $\mathrm{t}_{\text {stat }}>\mathrm{t}_{\text {critical one }}$ tail yaitu (-) 22,386>1,683 dengan demikian Ho ditolak yang berarti terdapat peningkatan pengetahuan rata-rata pada pengolah pindang sebelum dan sesudah dilaksanakannya pelatihan. Pratiwi et al. (2013) menyatakan bahwa peserta didik yang mendapatkan pengalaman belajar dengan cara melakukan akan dapat menyerap informasi sampai $90 \%$, peserta mendapatkan porsi praktek lebih banyak dibandingkan ceramah teori.

Tabel 3. Rata-rata pada uji-t berpasangan dua sampel

Table 3. $t$-Test Paired Two Sample for Means

\begin{tabular}{lll}
\hline \hline & Pre Test & Post Test \\
\hline Mean & 42,50871 & 85,01742 \\
\hline Variance & 321,3041 & 254,6043 \\
\hline Observations & 41 & 41 \\
\hline Pearson Correlation & 0,748338 & \\
\cline { 1 - 2 } Df & 40 & \\
\cline { 1 - 2 } $\mathrm{t}$ stat & $-22,3863$ & \\
\cline { 1 - 2 } $\mathrm{t}$ critical one tail & 1,683851 & \\
\hline \hline
\end{tabular}

Korelasi Antara Variabel X dan Y

Korelasi Variabel Karakteristik Inovasi $\left(X_{1}\right)$ dan Tingkat Adopsi $(Y)$

Tabel 4. Korelasi karakteristik inovasi (X1) dan tingkat adopsi (Y)

Table 4. Correlation of innovation characteristics $\left(X_{1)}\right.$ and adoption level $(Y)$

\begin{tabular}{|c|c|c|c|c|}
\hline & & & $\begin{array}{c}\text { Karakteristik } \\
\text { Inovasi }\end{array}$ & Tingkat Adopsi \\
\hline \multirow[t]{5}{*}{$\begin{array}{l}\text { Spearman's } \\
\text { rho }\end{array}$} & \multirow[t]{2}{*}{ Karakteristik Inovasi } & $\begin{array}{l}\text { Correlation } \\
\text { Coefficient }\end{array}$ & 1.000 & $.640^{* *}$ \\
\hline & & $\begin{array}{l}\text { Sig. (2-tailed) } \\
\mathrm{N}\end{array}$ & 41 & $\begin{array}{r}.000 \\
41\end{array}$ \\
\hline & \multirow[t]{3}{*}{ Tingkat Adopsi } & $\begin{array}{l}\text { Correlation } \\
\text { Coefficient }\end{array}$ & $.640^{* *}$ & 1.000 \\
\hline & & Sig. (2-tailed) & .000 & \\
\hline & & $\mathrm{N}$ & 41 & 41 \\
\hline
\end{tabular}


PELAGICUS: Jurnal IPTEK Terapan Perikanan dan Kelautan

Volume 2 Nomor 2: 95-106, Mei 2021

Tabel 5. Korelasi Indikator Karakteristik Inovasi $\left(\mathrm{X}_{1}\right)$ dengan Tingkat Adopsi (Y)

Table 5. Indicator Correlation of innovation characteristics $\left(X_{1)}\right.$ and adoption level $(Y)$

\begin{tabular}{|c|c|c|c|c|}
\hline No. & Indikator & o Spearman & Sig. (2-tailed) & Interpretasi Hubungan \\
\hline 1. & Relative advantage & 0,556 & $0,000 * *$ & $\begin{array}{l}\text { Cukup kuat, searah, } \\
\text { signifikan }\end{array}$ \\
\hline 2. & Compatibility & 0,505 & $0,001 * *$ & $\begin{array}{l}\text { Cukup kuat, searah, } \\
\text { signifikan }\end{array}$ \\
\hline 3. & Complexity & 0,569 & $0,000 * *$ & $\begin{array}{c}\text { Cukup kuat, searah, } \\
\text { signifikan }\end{array}$ \\
\hline 4. & Triability & 0,457 & $0,003 * *$ & $\begin{array}{c}\text { Cukup kuat, searah, } \\
\text { signifikan }\end{array}$ \\
\hline 5. & Observability & 0,254 & 0,110 & $\begin{array}{c}\text { Lemah, searah, tidak } \\
\text { signifikan }\end{array}$ \\
\hline
\end{tabular}

\section{Korelasi Variabel Karakteristik Pengolah Pindang $\left(X_{2}\right)$ dan Tingkat Adopsi $(Y)$}

Tabel 6. Korelasi Karakteristik Pengolah Pindang ( $\left.\mathrm{X}_{2}\right)$ dan Tingkat Adopsi (Y)

Table 6. Correlation of the characteristics of Pindang producer $\left(\mathrm{X}_{2}\right)$ and Adoption Level $(Y)$

\begin{tabular}{|c|c|c|c|c|}
\hline & & & $\begin{array}{c}\text { Karakteristik } \\
\text { Pengolah Pindang }\end{array}$ & $\begin{array}{l}\text { Tingkat } \\
\text { Adopsi }\end{array}$ \\
\hline \multirow[t]{3}{*}{ Spearman's rho } & $\begin{array}{l}\text { Karakteristik Pengolah } \\
\text { Pindang }\end{array}$ & $\begin{array}{l}\text { Correlation } \\
\text { Coefficient }\end{array}$ & 1.000 & $.358^{*}$ \\
\hline & & $\begin{array}{l}\text { Sig. (2-tailed) } \\
\mathrm{N}\end{array}$ & 41 & $\begin{array}{r}.022 \\
41\end{array}$ \\
\hline & Tingkat Adopsi & $\begin{array}{l}\text { Correlation } \\
\text { Coefficient } \\
\text { Sig. }(2 \text {-tailed }) \\
\mathrm{N}\end{array}$ & $\begin{array}{r}.358^{*} \\
.022 \\
41\end{array}$ & 1.000 \\
\hline
\end{tabular}

Tabel 7. Korelasi Indikator Karakteristik Pengolah Pindang $\left(\mathrm{X}_{2}\right)$ dan Tingkat Adopsi (Y) Table 7. Indicator correlation of the characteristics of Pindang producer $\left(X_{2}\right)$ and Adoption Level $(Y)$

\begin{tabular}{|c|c|c|c|c|}
\hline No. & Indikator & o Spearman & Sig. (2-tailed) & Interpretasi Hubungan \\
\hline 1. & Umur & 0,139 & 0,386 & $\begin{array}{l}\text { Sangat rendah, searah, } \\
\text { tidak signifikan }\end{array}$ \\
\hline 2. & Tingkat Pendidikan & 0,339 & $0,030 *$ & $\begin{array}{l}\text { Rendah, searah, } \\
\text { signifikan }\end{array}$ \\
\hline 3. & Pengalaman Usaha & 0,073 & 0,649 & $\begin{array}{l}\text { Sangat rendah, searah, } \\
\text { tidak signifikan }\end{array}$ \\
\hline 4. & Pendapatan & 0,090 & 0,577 & $\begin{array}{l}\text { Sangat rendah, searah, } \\
\text { tidak signifikan }\end{array}$ \\
\hline
\end{tabular}


Analisis Adopsi Teknologi ....... di Kabupaten Sukabumi (Prasetyati, et al)

\section{Korelasi Variabel Intensitas Pelatihan dan Kunjungan $\left(X_{3}\right)$ dan Tingkat Adopsi $(Y)$}

Tabel 8. Korelasi Intensitas Pelatihan dan Kunjungan $\left(\mathrm{X}_{3}\right)$ dan Tingkat Adopsi (Y)

Table 8. Correlation of The Intensity of Training and Visits $\left(X_{3}\right)$ and Adoption Level $(Y)$

\begin{tabular}{|c|c|c|c|c|}
\hline & & & $\begin{array}{c}\text { Intensitas } \\
\text { Pelatihan dan } \\
\text { Kunjungan }\end{array}$ & $\begin{array}{l}\text { Tingkat } \\
\text { Adopsi }\end{array}$ \\
\hline \multirow[t]{4}{*}{$\begin{array}{l}\text { Spearman's } \\
\text { rho }\end{array}$} & \multirow[t]{2}{*}{$\begin{array}{l}\text { Intensitas Pelatihan } \\
\text { dan Kunjungan }\end{array}$} & $\begin{array}{l}\text { Correlation } \\
\text { Coefficient }\end{array}$ & 1.000 & $.578^{* *}$ \\
\hline & & $\begin{array}{l}\text { Sig. (2-tailed) } \\
\mathrm{N}\end{array}$ & 41 & $\begin{array}{r}.000 \\
41\end{array}$ \\
\hline & \multirow[t]{2}{*}{ Tingkat Adopsi } & $\begin{array}{l}\text { Correlation } \\
\text { Coefficient }\end{array}$ & $.578^{* *}$ & 1.000 \\
\hline & & $\begin{array}{l}\text { Sig. (2-tailed) } \\
\mathrm{N}\end{array}$ & $\begin{array}{r}.000 \\
41\end{array}$ & 41 \\
\hline
\end{tabular}

**. Correlation is significant at the 0.01 level (2-tailed).

Tabel 9. Korelasi Indikator Intensitas Metode Pelatihan dan Kunjungan dengan Tingkat Adopsi Table 9. Indicator correlation of The Intensity of Training and Visits $\left(X_{3}\right)$ and Adoption Level (Y)

\begin{tabular}{clccc}
\hline \hline No. & Indikator & o Spearman & Sig. (2-tailed) & Interpretasi Hubungan \\
\hline 1. & Metode pelatihan & 0,568 & $0,000^{* *}$ & $\begin{array}{c}\text { Cukup kuat, searah, } \\
\text { signifikan }\end{array}$ \\
\hline 2. & Intensitas kunjungan & 0,397 & $0,010^{*}$ & Rendah, searah, signifikan
\end{tabular}

\section{Analisis Tingkat Adopsi}

Tabel 10. Waktu Adopsi Inovasi Teknologi

Table 10. Time for Adoption of Technological Innovation

\begin{tabular}{|c|c|c|c|c|}
\hline "Jawaban Responden & Frekuensi & Persentase & Rata-Rata & Standar Deviasi \\
\hline Sesaat paska pelatihan & 20 & $48,78 \%$ & 3,8 & 1,49 \\
\hline 1 bulan paska pelatihan & 9 & $21,95 \%$ & & \\
\hline 2 bulan setelah pelatihan & 1 & $2,44 \%$ & & \\
\hline 3 bulan setelah pelatihan & 6 & $14,63 \%$ & & \\
\hline Tidak menerapkan & 5 & $12,19 \%$ & & \\
\hline
\end{tabular}

\section{Analisis Kelayakan Usaha}

Tabel 11. Analisis Kelayakan Usaha

Table 11. Analysis of Business Feasibility

\begin{tabular}{clc}
\hline \hline No & Indikator Analisis & Nilai \\
\hline 1. & Revenue Cost Ratio & 1,58 \\
2. & Break Even Point & 38 botol/bulan \\
3. & Payback period & 1,26 \\
\hline \hline
\end{tabular}

\section{BAHASAN}

Analisis Hasil Pre dan Post Test

Pratiwi et al (2013) menyatakan bahwa siswa yang mendapatkan pengalaman belajar dengan cara melakukan akan dapat menyerap informasi sampai 90\%. Peserta mendapatkan porsi praktek lebih banyak dibandingkan ceramah teori dalam kegiatan pelatihan. Dalam pelatihan, 
peserta mendapatkan porsi praktek lebih banyak dibandingkan ceramah teori. Sebanyak 13 orang peserta memperoleh kenaikan nilai sebesar $28,57 \%$; 18 orang memperoleh kenaikan nilai sebesar $42,86 \%$; 8 orang memperoleh kenaikan nilai sebesar 57,14\%; dan 2 orang memperoleh kenaikan nilai sebesar $71,43 \%$.

Frisdiantara et al dalam Anwas (2013) menyebutkan bahwa pelatihan memberikan pengaruh secara signifikan dalam memperkuat kompetensi lulusan sarjana akuntansi. Berdasarkan hasil analisis data pre dan post test pada pelatihan teknologi pembuatan petis, dapat dilihat bahwa pelatihan memperkuat kompetensi pengolah pindang yakni dari sisi peningkatan pengetahuannya. Pada saat wawancara didapatkan informasi bahwa rata-rata responden jarang mengikuti kegiatan pelatihan yang diadakan oleh Penyuluh. Keseluruhan responden menjawab bahwa pelatihan pengolahan petis merupakan pelatihan kedua yang diikuti setelah sebelumnya mengikuti pelatihan "Penerapan Sanitasi dan Higiene dalam Pengolahan" yang dilakukan oleh P2MKP Minanggala dalam rentang waktu lima tahun.

Anwas (2013) menjelaskan bahwa rendahnya frekuensi/ jumlah pelatihan yang diikuti oleh penyuluh pertanian menyebabkan kompetensi penyuluh juga rendah, sehingga frekuensi pelatihan dianggap mempengaruhi kompetensi seseorang. Rendahnya partisipasi masyarakat Kabupaten Sukabumi dalam kegiatan penyuluhan diduga salah satu penyebabnya adalah minimnya kegiatan penyuluhan yang menggunakan metode sesuai dengan kebutuhan masyarakat. Hal ini didukung oleh pernyataan dari Penyuluh Perikanan Kabupaten yang diwawancarai oleh peneliti, bahwa kegiatan penyuluhan menjadi tanggung jawab BP4K dimana porsi kegiatan untuk penyuluhan perikanan dalam satu tahun anggaran sangatlah minim. Kegiatan pelatihan maksimal dilakukan satu kali dalam satu tahun dengan pelaksanaan di kecamatankecamatan prioritas. Jumlah sasaran pelatihan terbatas sesuai dengan anggaran yang tersedia, biasanya berkisar antara 20-30 orang.

\section{Korelasi Antara Variabel $X$ dan $Y$}

Tabel 4 menunjukkan koefisien korelasi antara karakteristik inovasi secara keseluruhan dengan tingkat adopsi teknologi petis yaitu 0,640 dan memiliki nilai sig-2 tailed 0,000 yang berarti karakteristik inovasi memiliki hubungan kuat terhadap tingkat adopsi teknologi dan signifikan. Arah hubungan ditunjukkan oleh koefisien korelasi yang bernilai positif yang berarti jika nilai variabel $\mathrm{X}_{1}$ tinggi maka nilai variabel $\mathrm{Y}$ juga tinggi, dimana semakin baik persepsi responden terhadap karakteristik inovasi maka semakin cepat adopsi teknologi yang terjadi. Hal ini sejalan dengan pernyataan Rogers (1983) bahwa kecepatan adopsi salah satunya ditentukan oleh sifat-sifat inovasinya. Harinta (2010) menjelaskan bahwa keuntungan relatif memberikan pengaruh signifikan terhadap adopsi inovasi pertanian. Yaitu semakin besar relative advantage (keuntungan relatif) yang didapat, maka akan semakin cepat adopsi inovasi terjadi. Harinta (2010) juga menyebutkan bahwa tingkat kemudahan inovasi akan mempercepat proses adopsi. Selain itu triabilitas juga berpengaruh secara signifikan terhadap adopsi inovasi, artinya suatu inovasi yang tingkat ketercobaannya tinggi maka akan mempercepat adopsi inovasi tersebut.

Tabel 5 menunjukkan koefisien korelasi antara lima indikator karakteristik inovasi dengan tingkat adopsi teknologi petis. Lima indikator pada karakteristik inovasi memperlihatkan hasil bahwa hanya indikator observability yang korelasinya lemah dan tidak signifikan. Indikator 
observability tidak menjadi pertimbangan bagi responden untuk mengadopsi inovasi teknologi. Empat indikator yang lain menunjukkan korelasi cukup kuat, searah dan signifikan. Hal tersebut sesuai dengan pernyataan Harinta (2010) bahwa semakin positif pendapat responden terhadap relative advantage, compatibility, complexity dan triability akan mempercepat tingkat adopsi inovasi teknologi di masyarakat.

Tabel 6 menunjukkan koefisien korelasi antara karakteristik pengolah pindang secara keseluruhan dengan tingkat adopsi teknologi petis yaitu 0,358 yang berarti karakteristik pengolah pindang memiliki hubungan rendah terhadap tingkat adopsi teknologi. Arah hubungan ditunjukkan oleh koefisien korelasi yang bernilai positif yang berarti jika nilai variabel $\mathrm{X}_{2}$ tinggi maka nilai variabel $Y$ juga tinggi, dimana semakin baik karakteristik pengolah pindang maka semakin cepat adopsi teknologi yang terjadi. Hal ini sesuai dengan pernyataan Sutarto (2008) bahwa faktor umur, pendidikan, luas lahan, pendapatan dan pengalaman petani akan mempengaruhi keputusan petani dalam mengadopsi teknologi yang ditawarkan Penyuluh..

Berdasarkan hasil analisis korelasi pada Tabel 7, indikator umur; pengalaman usaha dan pendapatan memiliki hubungan yang sangat rendah dan tidak signifikan. Satu-satunya indikator yang berhubungan signifikan dengan tingkat adopsi adalah tingkat pendidikan meskipun dengan korelasi yang rendah. Sutarto (2008) menyatakan bahwa pendidikan formal atau non formal akan berpengaruh pada cara berfikir petani pada saat melakukan rasionalisasi usaha dan juga mempengaruhi petani pada kemampuan memanfaatkan setiap kesempatan yang ada. Semakin tinggi pendidikan formal seseorang maka akan semakin tinggi pula kemampuan untuk memilah, menerima dan menerapkan inovasi yang diberikan padanya. Responden dengan tingkat pendidikan
SLTP dan SLTA termasuk dalam responden dengan waktu adopsi lebih cepat dari responden dengan pendidikan SD.

Tabel 8 menunjukkan koefisien korelasi antara variabel intensitas pelatihan dan kunjungan secara keseluruhan dengan tingkat adopsi teknologi petis yaitu 0,578 dan memiliki nilai sig- 2 tailed 0,000 yang berarti variabel intensitas pelatihan dan kunjungan memiliki hubungan cukup kuat terhadap tingkat adopsi teknologi dan signifikan pada $\alpha 0,01 \mathrm{dn} 0,05$. Arah hubungan ditunjukkan oleh koefisien korelasi yang bernilai positif yang artinya semakin tinggi nilai variabel $\mathrm{X}_{3}$ maka semakin tinggi pula nilai variabel $\mathrm{Y}$, dimana semakin bertambah frekuensi pelatihan dan kunjungan maka semakin cepat teknologi akan diadopsi. Hal ini sesuai dengan pernyataan Anwas (2013) bahwa intensitas pelatihan mempengaruhi kompetensi seseorang, dimana kompetensi erat kaitannya dengan perubahan perilaku (dalam hal ini adalah adopsi inovasi teknologi).

Tabel 9 memperlihatkan bahwa indikator metode pelatihan memiliki hubungan cukup kuat, searah dan signifikan. Berdasarkan hasil wawancara diketahui bahwa responden yang menyatakan setuju dan sangat setuju menganggap pelatihan efektif untuk menjadi metode penyampaian inovasi teknologi. Responden menginginkan adanya kunjungan yang teratur dan rutin ke kelompok.

\section{Analisis Tingkat Adopsi}

Data Tabel 10 menunjukkan waktu yang dibutuhkan oleh masyarakat untuk menerima inovasi teknologi yang diberikan. Penerimaan masyarakat terhadap inovasi teknologi tertentu dikenal dengan istilah adopter. Rogers \& Shoemaker dalam Mardikanto (2009) menyebutkan bahwa adopter diklasifikasikan menjadi lima jenis yakni innovator; early adopter; early majority; 
late majority; dan laggard. Indikator waktu adopsi teknologi menunjukkan bahwa responden yang mengadopsi inovasi teknologi dalam kurun waktu satu sampai dua bulan setelah pelatihan termasuk dalam kategori early majority yakni sebanyak 29 orang $(70,73 \%)$. Sebanyak 7 orang $(17,07 \%)$ lainnya yang mengadopsi inovasi teknologi setelah dua bulan pelatihan sampai berakhirnya masa pengamatan termasuk dalam kategori late majority; 5 orang $(12,20 \%)$ yang tidak bersedia menerapkan inovasi teknologi termasuk dalam kategori laggard. Tingginya jumlah early majority diduga disebabkan oleh faktor karakteristik inovasi terutama keuntungan ekonomi, kemudahan inovasi, serta kesesuaiannya dengan kultur masyarakat setempat. Metode pelatihan dan kunjungan juga dianggap tepat dalam menyampaikan inovasi teknologi sehingga responden tertarik untuk mengadopsinya. Adapun untuk kategori laggard, keengganan untuk mengadopsi inovasi teknologi diduga karena mereka cenderung belum percaya akan manfaat inovasi baru sehingga tidak bersedia untuk mengadopsinya (Harinta, 2010).

\section{Analisis Kelayakan Usaha}

Nilai revenue cost ratio (R/C Ratio) usaha pembuatan petis adalah 1,58 yang berarti bahwa usaha tersebut menguntungkan. Sebagaimana yang dinyatakan oleh Wahyuningsih et al. (2013) jika R/C Ratio > 1 maka usaha yang dijalankan dapat diteruskan (menguntungkan). Nilai BEP dari usaha pembuatan petis adalah 464 botol pada tahun pertama yang berarti tingkat penjualan yang mengakibatkan keadaan usaha tidak mengalami keuntungan atau kerugian (impas) jika pengolah pindang dapat menjual 464 botol petis per tahun atau sekitar 38 botol per bulan. Nilai Payback period usaha pengolahan petis dari air rebusan pindang adalah 1,26 yang berarti investasi akan kembali dalam waktu satu tahun tiga bulan.

\section{SIMPULAN}

Hubungan karakteristik inovasi terhadap tingkat adopsi inovasi pengolah pindang adalah kuat, signifikan dan berbanding lurus yang artinya semakin baik persepsi responden terhadap karakterisik inovasi teknologi akan semakin cepat pula proses adopsi teknologi. Hubungan karakteristik calon pengguna terhadap tingkat adopsi inovasi pengolah pindang adalah rendah, signifikan dan berbanding lurus; intensitas metode pelatihan dan kunjungan berhubungan cukup kuat, signifikan dan searah dengan tingkat adopsi inovasi. Artinya semakin sering responden diberikan pelatihan dan dikunjungi maka semakin cepat adopsi teknologi yang terjadi. Terdapat penambahan pendapatan sebagai outcome penyuluhan dihasilkan dari kegiatan diversifikasi olahan air rebusan pindang menjadi petis ikan.

\section{DAFTAR PUSTAKA}

Amanah, S. (2006). Penyuluhan Perikanan. Jurnal Penyuluhan, 2 (4), 62-69.

Anwas, O. M. (2013). Pengaruh Pendidikan Formal, Pelatihan dan Intensitas Pertemuan terhadap Kompetensi Penyuluh Pertanian. Jurnal Pendidikan dan Kebudayaan, 19 (1), 50-62.

Erlina, M. D. \& Kurniasari, N. (2007). Adopsi Teknologi Palka Berinsulasi Untuk Penanganan Ikan Segar di Pelabuhanratu, Sukabumi. Jurnal Perikanan, IX (2), 241-253.

Harinta, Y.W. (2010). Faktor-faktor yang Mempengaruhi Kecepatan Adopsi Inovasi Pertanian di Kalangan Petani di Kecamatan Gatak Kabupatn Sukoharjo. Tesis. Universitas Sebelas Maret. Surakarta. 
Peraturan Menteri Kelautan dan Perikanan Republik Indonesia No. 30/PERMEN-KP/2014 tentang Mekanisme Kerja dan Metode Penyuluhan Perikanan. 12 Agustus 2014. Jakarta.

Maimun, Syarif, S., \& Bestynar, K. S. (2013). Statistika Terapan Untuk Ilmu Eksakta, Sosial dan Behavioral. STP Press. Jakarta. Hal: 102.

Maimun, Syarif, S., \& Bestynar, K. S. (2014). Analisa Kuantitatif Untuk Penelitian dan Pengambilan Keputusan. STP Press. Jakarta. Hal: 103

Mardikanto, T. (2009). Sistem Penyuluhan Pertanian. Lembaga Pengembangan Pendidikan UNS dan UPT Penerbitan dan Percetakan UNS. Surakarta. Hal: 91-92.

Neolaka, A. (2014). Metode Penelitian dan Statistik. PT Remaja Rosdakarya. Bandung. Hal: 128.

Pertiwi, P. R., Farida, I., \& Noviyanti, R. (2011). Karakteristik Adopter pada Masyarakat Nelayan Kampung Cipatuguran Palabuhanratu dalam Menerima Teknologi Baru. Jurnal Penyuluhan, 7 (1), 1-9.
Rogers, E. M. (1983). Diffusion of Innovation. Third Edition. The Free Press. New York. Page: 5. 453 pages.

Sutarto. (2008). Hubungan Sosial Ekonomi Petani Dengan Tingkat Adopsi Inovasi Teknologi Komoditas Jadung Di Sidoarjo Wonogiri. Jurnal Agritext, 24 (2), $1-10$.

Wahyuningsih, I., Usman, E., \& Arif, H. (2013). Analisis Kelayakan Usaha Produksi Sambal Petis Ikan Tuna Siap Saji Tesis. Universitas Brawijaya. Malang.

Widianto, I. D. (2015). Analisis Tingkat Partisipasi Pembudidaya Rumput Laut dalam Kegiatan Penyuluhan di Kota Bontang. Tesis. Sekolah Tinggi Perikanan. Jakarta. 139 halaman.

Wijianto, A. (2008). Hubungan antara Peranan Penyuluhan Dengan Partisipasi Anggota dalam Kegiatan Kelompok Tani di Kecamatan Banyudono Kabupaten Boyolali. Jurnal Agritext, 24 (2), 115-128. 